\title{
The Leading Volodymyr Pidvysotskyi's Scientific School of Pathophysiologists
}

\author{
Liudmila Klymenko \\ Bogomolets National Medical University \\ Zhukova 35, 59 \\ Kyiv 02156, Ukraine \\ E-mail: rfpbvrj@ukr.net
}

\begin{abstract}
This article describes the achievements of the pathophysiological school established by Volodymyr Valerianovych Pidvysotskyi (18571913), founder of the first school of pathologists, immunologists, and microbiologists in Ukraine. The contribution of the scientific school of thought can be confirmed in insights into hepatic tissue regeneration, as well as biomedical research in the field of bacteriology and immunology. Among Pidvysotskyi's students were the famous scientists O. F. Mankovskyi, I. G. Savchenko, S. M. Schastnyi, L. O. Tarasevich, D. K. Zabolotnyi, V. O. Taranukhin, F. I. Lominskyi, and others. The purpose of this article is to present the achievements of the first Ukrainian school of pathophysiologists.
\end{abstract}

Key words: immunity, oncology, pathophysiology, scientific school

Volodymyr Podvysotsky "generously sowed the seeds of scientific thoughts and ideas which later yielded great harvest in the native medical science."

(K. G. Vasiliev)

One of the decisive factors in the formation and development of any discipline, including medical science, is the achievement of scientific schools. Progress in medical knowledge in Ukraine is inextricably linked with the activities of members of schools of pathology. Among such figures was Volodymyr Valerianovych Pidvysotskyi (1857-1913), who founded the first 
native school of pathologists in Ukraine. His personal scientific achievements and activities of the school's members played a key role in the development of the Ukrainian national pathophysiology.

Volodymyr Pidvysotskyi was born in Ukraine, in the village of Maximivka in the Chernihiv region. Pidvysotskyi graduated from the Kyiv University of St. Volodymyr, and carried out most of his research in Kyiv. During his university years he wrote his first scientific work about the history and medical significance of kefir. The study was reprinted five times and was later published in Germany and France (Podvysotsky, 1884). ${ }^{1}$

In 1884, Pidvysotskyi traveled abroad to study and work (Derzhavnyi arkhiv, F 16, c 4806, op 465, p. 23). The young-scientist trained in Germany, worked in the laboratories of the pathologist Ziegler, the physiologist Grützner, and the physicist Hoffner. The results of his scientific research during this period became the basis of his dissertation, published under the title which could be translated as Regeneration of the Liver Tissue of Mammals (Experimental Research) (Ruda, 2007). In its preface it was noted that the work was carried out at the Pathological Institute of Professor Ziegler in Tübingen. The dissertation describes observations on development of liver pathology in acute phosphorus and arsenic poisoning. In this doctoral thesis, the pathological phenomena of the local necrosis of the liver parenchyma that occur in addition to fatty degeneration were represented for the first time. The bile ducts remain unchanged in this pathology. In 1886, during his short visit to Kyiv, Pidvysotskyi defended the dissertation.

Pidvysotskyi soon left Ukraine to continue his travels abroad to learn about new pathophysiological research methods. He worked first with the pathologist Bollinger in Munich, then in the laboratory of Louis Pasteur in Paris. In Paris he studied bacteriology, pathological histology, and physiological chemistry. Working together with such well-known scientists had an effect on the formation of Pidvysotskyi's scientific outlook. He returned to Ukraine with new ideas and enthusiasm that allowed the development of pathophysiological research in Ukraine. His first works concerned histological studies, then he studied the problem of bacteriology. The main field of research of his students was bacteriology as well as the study of microbiology.

While staying abroad, he not only trained, but also did a lot of investigation

1 The different spelling of names and institutions in the text and in the list of references stem from Russian and Ukrainian transliteration variations. 
for the development of French science. In 1895, he was awarded a medal by the French government for his merits in the study of mineral waters of France (CDIAK, F 708, op 337, p. 49).

In 1887, Volodymyr Pidvysotskyi was appointed a private associate professor of the Department of General Pathology at the University of St. Volodymyr. On August 1, 1888, he was approved as extraordinary professor, following the retirement of Professor N. Khrzhnchevskyi. Volodymyr Pidvysotskyi headed the department until 1890 .

Pidvysotskyi, enlightened with considerable scientific information at the Pasteur Institute, set up an active and effective teaching program of pathology, focusing more on bacteriology in the curriculum. Inspired by Pasteur's scientific works, he introduced experimental demonstration in medical teaching. At his lectures, he often showed various bacterial and histological preparations.

Pidvysotskyi's students and researchers of his creativity argue that his formation as a scientist took place in Kyiv at the University of St. Volodymyr (Zabolotnyy, 1957; Podvysotsky, 1886; Syrotynyn, 1964; Klymenko, 1957; Vasilyev, Zaporozhan \& Zanchevskaya, 2003). Many famous Ukrainian scientists took their first steps in this university. Pidvysotskyi loved science most of all, which explains his great enthusiasm in conducting pedagogical and scientific work at the department. He quickly achieved academic recognition and authority among students and researchers. His students point out that Pidvysotskyi was a talented lecturer. What made his lectures successful were the simplicity and, accessibility of the presentation of the material, and at the same time, the richness of the content of his lectures. The lectures were filled with information on new advances in science and data from different branches of medicine.

Progress in pathophysiology and medicine is inevitably experimental. However, the department was understaffed because P. Peremechko was seriously ill, N. Khrzhnchevskyi had retired, and G. Minkh was busy with expeditions to study leprosy, plague, and anthrax. Pidvysotskyi, with his enthusiasm and the gift for encouraging youth, attracted practical doctors and students to become involved in scientific research work. The positions in Pidvysotskyi's laboratory were constantly occupied, so students were waiting for their turn for months. Pidvysotskyi was a brilliant scientist. He managed to obtain research equipment that was very modern at that time. D. K. Zabolotnyi, who at that time studied at the Kyiv University, wrote in his memoirs: 
Each of us, his students, who had the good fortune to work in his laboratory, remember the youth years with hope and the wide range of scientific plans, inextricably linked with our memories of the cosy working corner and the enthusiastic personality of V. V., whose lively language, unusual mobility, and penetrating curious glance, are impossible to forget (Zabolotnyi, 1957, p. 285).

With Pidvysotskyi's arrival at the Department of General Pathology of the University of St. Volodymyr, experimental research essentially intensified. His first significant part of scientific activity in Kyiv were researches in the field of regeneration of glandular tissue (Podvysotsky, 1886). Pidvysotskyi carefully elaborated on the issues of regeneration of the liver, lymph glands, and the fine structure of cells. This problem became a key to the establishing of scientific school of pathologists at the Kyiv University. The pathophysiologist M. Sirotinin noted that the development of the regeneration of hepatic tissue was one of the great merits of the scientist. Pidvysotskyi's scientific materials have not lost their significance also after his death (Syrotynyn, 1964).

Pidvysotskyi's activity was prodigious. Namely in Kyiv, he became head of the scientific school where rich inspiration prevailed and where well-known figures of medical science later came from. Among his first pupils were O. F. Mankovsky, I. G. Savchenko, S. M. Schastnyi, L. O. Tarasevich, D. K. Zabolotnyi, V. O. Taranukhin, and F. I. Lominskyi. Stimulated by the scientific ideas around the young scientists, the young researchers (V. O. Afanasyev, O. V. Leontovich, G. I. Zeleny, M. F. Obnyskyi, L. A. Zilberberg and others) would later group together.

At that time, the two directions of scientific work were established at the department: the traditional experimental-morphological, and the new medicalbiological research in the area of bacteriology and immunology. The latter was associated with the development of bacteriological and immunological knowledge, especially with I. I. Mechnikov's works, with whom Pidvysotskyi closely collaborated and whose views he fully shared.

Regarding his morphological studies during the Kyiv period, Pidvysotskyi's scientific activity could be included among the works devoted to issues of oncology. His study on malignant tumours was of the greatest importance in this respect (Podvysotsky, 1908). He demonstrated for the first time the importance of mechanical, physical, and chemical stimuli in the emergence of tumours. Pidvysotskyi discovered the microorganism Coccidium oviform in human liver cells. That observation marked the beginning of the doctrine of microparasitic 
origin of malignant tumours. Although those studies did not have evidence that this microorganism caused the development of malignant tumours, the findings of the scientist suggested that the simplest microparasites can be found in both normal organ cells and human blastomas.

The other direction of Pidvysotskyi's studies was bacteriological research, which became the basis of his scientific achievements. Pidvysotskyi's long friendship with Mechnikov, whose phagocytic theory he warmly supported, facilitated the research. In 1892-1895, Pidvysotskyi published a series of works about the morphology of Vibrio cholerae and the causative agent of Siberian ulcer. When studying the morphology of Vibrio cholerae on various nutrient media he had found a change in the size and shape of the bacterium, depending on reaction to the environmental composition (Vasilyev, Zaporozhan \& Zanchevskaya, 2003).

The wide scope of bacteriological research resulted in the formation of Pidvysotskyi's microbiological school. Among his students were the well-known scientists I. G. Savchenko, D. K. Zabolotnyi, L. O. Tarasevich, S. M. Schastnyi, F. F. Skshivan, V. K. Stefanskyi, V. Z. Omelchenko, and others. Pidvysotskyi's laboratory in Kyiv became one of the best known microbiological centres in the country. In this laboratory, in 1893, Danylo Zabolotnyi and Ivan Savchenko conducted the heroic trial of self-infecting with cholera and thus proved the possibility of vaccination against this disease by mouth.

Ivan Grigorovich Savchenko (1862-1932) discovered single-cell spore microorganisms in cancer cells. He suggested that spore microorganisms can cause cancer, or adversely affect the clinical picture of cancer, producing toxic substances. The data obtained by the young scientist were quite significant, so Volodymyr Valerianovich Pidvysotskyi supported those studies and sent a telegram about Savchenko's findings to Mechnikov. The results of Savchenko's studies were summarized in the dissertation (Savchenko, 1894). Actually, those observations demonstrated the role of living exogenous parasites in cancerous processes. The conclusions that Savchenko made were not absolutely correct, but the significance of these observations was that they lead other researchers on the path of further investigations in the aetiology of cancerous processes. Subsequently, scientists rejected this hypothesis. However, in recent years, many studies about the influence of virus on the development of cancer have been published. Thus, Savchenko's hypothesis somewhat coincides with the modern representations of the viral aetiology of tumours: the formation of some types of tumours may be associated with a live pathogen. Savchenko later became a professor at the University of Kazan. 
Danylo Kyrylovych Zabolotnyi (1866-1929), owing to his research, became the founder of epidemiology as an independent discipline. He considered microbiology as a discipline closely related to medicine, which the scientific ideology of a doctor is based on. Danilo Zabolotnyi often visited places of plague and cholera epidemics. In 1904-1909, he carried out active research on cholera in Russia. But his main area of scientific study was researching plague. During the period of 1913-1914, Zabolotnyi practically completed the study of this issue and, as a result, proposed the doctrine of the epidemiology of plague and substantiated the system of preventive and anti-epidemiological measures. Zabolotnyi was elected academician of the Academy of Sciences of Ukraine in 1926 and in 1928 he became the president of the Academy of Sciences of Ukraine.

Lev Alexandrovich Tarasevich (1869-1958), who was also a student of Pidvysotskyi, explored the interesting phenomena of changes in human central nervous system that occur during starvation (Tarasevich, 1898). Subsequently, those studies became the basis for the further development of this problem with a purpose of solving the issues of prevention.

Tarasevich carried out various experiments in the field of immunology and medical microbiology. In his writings he always referred to the theory of I. I. Mechnikov. His dissertation On the Doctrine of Haemolysins. Historical-Critical and Experimental Research (1902) was based on the results he obtained in Mechnikov's laboratory at the Pasteur Institute. He proved that antibodies are produced mainly in spleen and lymph nodes. These studies on haemolysins were of great importance for the development of the doctrine of the role of the reticulo-endothelial system in immunity and the doctrine of anaphylaxis. Subsequently, the main directions of his work were: definition of morbidity, natural immunization, the formation of immunity to tuberculosis, cholera, typhoid, malaria, rash typhoid, dysentery, and syphilis pathogens. Later Tarasevich moved to Moscow and became a professor of Moscow Women's courses.

Fedir Ivanovych Lominskyi (1856-1927) carried out interesting research in Pidvysotskyi's laboratory. First, he investigated plant parasites. After defending his dissertation, Lominskyi started work as a project assistant at the Department of Histology of St. Volodymyr University, which put a start to his scientific and pedagogical practice (Derzhavnyi arkhiv, F 16, op 330). In 1906, Fedir Lominskyi was appointed as professor of the Department of Histology and Embryology of the University of St. Volodymyr. Historians of science consider Lominskyi the founder of modern histophysiological direction of research (Gamaliya, 2013). 
Lominskyi also carried out original studies on crystalline lens microstructure, muscles and tendons, physiological degeneration of strained muscle fibres, reactive changes in exo- and endocrine parts of pancreas, and so on. Lominskyi's main scientific focus, however, was his achievements in investigation of dividing and degeneration of nerve cells. He found that neurogenesis occurs through karyokinesis (mitosis) (Lomynsky, 1882). Certainly, at that time nothing was known about stem cells. Stem cell research grew out of the findings of Ernest A. McCulloch and James E. Till at the University of Toronto in the 1960s. However, according to the modern conception embryonic neurogenesis begins with mitotic stem cells that give rise to differentiated neurons which migrate to different parts of the brain. Also, recent studies have shown the presence of neurogenesis in adults due to the presence of nerve stem cells in olfactory bulb. These stem cells are also divided by mitosis and pass through several stages before neuron formation (Geraschenko, Deltsov \& Chaikovsky, 2013; Ming \& Song, 2011). All this is evidence that Lominskyi's study was quite a contribution to the history of science.

Pidvysotskyi started each new study with great enthusiasm. He always discussed his plans with his students. Having formed a new idea, Pidvysotskyi immediately shared it with his followers, and he himself proceeded to the planning and conducting of new scientific works. For example, Pidvysotskyi was interested in endocrinology and decided to guide his student Olexander Mankovskyi to investigate the secretory function of adrenal glands and pancreas. In 1888, Olexander Fedorovich Mankovskyi (1868-1946), under Pidvysotskyi's direction, was the first to obtain adrenaline that is released from adrenal glands and called it "adrenal stimulus". Two works have to mentioned in connection with that, 'On the toxic effect of extraction of adrenal glands in death during chloroform anaesthesia' (1897), and 'The simplest methods of adrenal extraction and its effect on animal's organism' (1898). Mankovskyi showed that adrenal gland secretions increase blood pressure. Moreover, the dose which is necessary for a physiological effect is much lower than its toxic effect. Mankovskyi also studied the morphofunctional organization of pancreas.

Another significant figure of this period was Olexandr Vasilyevich Leontovich (1869-1943), who began his scientific work in the laboratory of Pidvysotskyi studying human skin innervation. Later he became the well-known Ukrainian physiologist and neurohistologist who performed pioneering investigations of nerve structures by coloring methylene blue and described the autonomic peripheral nerve plexus (Leontovich's plexus). 
Pidvysotskyi's great merit lied in the organization of preventive measures against infectious diseases. As a member of the Society for the Control of Infectious Diseases, in 1892, he led a group of doctors to fight the epidemic of cholera, was personally in charge of cholera barracks, actively participated in advocating medical knowledge, and trained nurses.

During 1896-1902, one of the best medical journals, Russkii arkhiv patologii, klinicheskoi meditsiny $i$ bakteriologii (Russian archive of pathology, clinical medicine and bacteriology) was regularly published, and Pidvysotskyi was its founder and editor-in-chief. Members of the journal's editorial board and Pidvysotskyi's coworkers often sat in the evenings in the editorial office, discussing plans for the next issue of the journal. Many famous Russian scientists published their articles in this journal, among them I. I. Mechnikov, V. V. Pashutin, M. G. Ushinskyi, N. Y. Chistovich, and others.

The Odessa period in Pidvysotskyi's scientific work, began on May 1900 with his appointment as dean of the newly established medical faculty at the Novorossiysk University (Odessa). This period was marked by the continuing formation of his scientific school and his wide organizational activity. Pidvysotskyi actually became the founder of the faculty of medicine at the university. As a talented organizer, he hired a staff of professors and highly skilled lecturers for the medical faculty. The organizational work took a lot of time, but Pidvysotskyi managed to combine that work with the educational and scientific process in the medical faculty. He was responsible for preparing the program for the educational process in the medical faculty in the first year.

In Odessa, Pidvysotskyi continued the publishing activities. In these years, the second edition of the manual on fundamentals of general pathology was published. In the manual, considerable attention was paid to the questions of the morphology and physiology of pathogenic organisms, pathology of cells, individual organs and systems, and problems of immunity. At this time, Pidvysotskyi was also editor of the journal Russian Doctor's.

Despite his involvement in various organizational and administrative events, Pidvysotskyi managed to supervise his students' academic work. O. F. Mankovskyi, L. O. Tarasevich, S. M. Schastnyi, V. K. Stefanskyi, O. O. Bogomolets and other scientists worked under his lead in Odessa. Pidvysotskyi and his coworkers continued bacteriological and microbiological experiments as well as immunological research. Another, no less famous figure in the development of medicine was Oleksander Mankovskyi, whose work was discussed above. $\mathrm{He}$ 
also moved to Odessa and lived there for 20 years. Mankovskyi also made a great contribution to the history of medical education in Ukraine. He was one of the founders of the Novorossiysk University. In 1907-1909, Mankovskyi worked as secretary of the university's Faculty of Medicine, and in 1907-1910, he became vice rector.

Unfortunately, in 1920, Mankovskyi was forced to emigrate from Ukraine because of revolutionary unrest in Odessa. The scientist was offered the position of the head of the Department of Histology and Embryology, and the Faculty of Medicine of Sofia University, where he worked until 1929. Tsar of Bulgaria Boris III awarded Mankovskyi for his merits the Order of St. Alexander of the III Degree.

In Odessa, a talented student, Olexandr Olexandrovich Bogomolets (1881-1946) began his activity under the direction of Pidvysotskyi. In 1905, Bogomolets investigated in Mankovskyi's laboratory the microscopic structure of adrenal glands, and published the obtained results in the paper 'On the question of changes in adrenal glands in experimental diphtheria'.

Among the students who worked with Pidvysotskyi in Odessa was Vyacheslav Karlovych Stefanskyi (1867-1949), who was known for his work on the aetiology and pathogenesis of many infectious diseases, in particular, diphtheria (Stefansky, 1912). Stefanskyi discovered and in detail described the causative agent of leprosy in rats (Stefansky's bacillus). In 1921, he founded the first independent department of infectious diseases in Odessa.

In 1905, Volodymyr Pidvysotskyi, unfortunately, left Ukraine because he was appointed the director of the Imperial Institute of Experimental Medicine in St. Petersburg and at the same time head of the Department of General Pathology. In St. Petersburg he focused on the study of oncology, especially the possibility of chemotherapy. He was also involved in publishing activities and became editor of the journal Archive of Biological Sciences.

Pidvysotskyi made a significant contribution to the popularization of Russian and Ukrainian science. His works were published abroad in various medical journals. He often travelled to foreign countries to participate in international forums. In 1900, Pidvysotskyi was elected the honorary president of the 13th International Medical Congress in Paris. In 1901, he travelled to Germany for the anniversary of Rudolf Virchow. About his trip he wrote the article 'Anniversary Gift to Rudolf Virchow' in which he expressed his admiration of this brilliant scientist. 
In 1912, Pidvysotskyi took part in the World Hygiene Exhibition in Dresden as chairman of the Russian delegation. He skilfully organized this exhibition, where many objects from Russia and Ukraine were displayed: serum and vaccines (from Ukraine), stuffed rodents which transmit infections, cartograms, dummies and illustrations about the state of various factories and manufactures (in Russia). B. I. Klein wrote that the Russian exhibition in Dresden had been the best despite the fact that the level of sanitary business in Russia was lower than in Europe (Klein, 1957). This is evidence of Pidvysotskyi's excellent organizational skills. After that he was awarded the title of Ordinary Honorary Member of the Royal Institute of Experimental Therapy in Frankfurt am Main.

After his return to Russia he spent a few months to prepare for the Russian Hygiene Exhibition. Unfortunately, within a year he became ill and died.

It should be noted that many Pidvysotskyi's students founded their own schools. In particular, D. K. Zabolotnyi established his school of epidemiologists, and V. Ch. Stephansky founded his school of infectious diseases.

L. O. Tarasevich also managed to start his immunological scientific school. The main directions of the scientific activity of Tarasevich's school were microbiological and epidemiological studies, directly related to the organization of preventive and anti-epidemiological measures. Together with his collaborators, Tarasevich paid a lot of attention to the development of the most optimal technology of vaccine production, quality control, as well as to studying and implementation of new health care products.

Among Pidvysotskyi's followers, also O. O. Bogomolets was an outstanding person. From 1930 to the end of his life he worked as President of the Academy of Sciences of Ukraine and at the same time as director of the Institute of Clinical Physiology in Kyiv. Bogomolets was a member of the Academy of Sciences and the Academy of Medical Sciences of the USSR, a Hero of Socialist Labour, the deputy of the Supreme Soviets of the Ukrainian SSR and the USSR. He founded a large school of pathophysiologists.

Thus, Volodymyr Pidvysotskyi's versatile activities and his students played a great role in the development of pathological science in Ukraine and left an indelible mark on the development of medical science as a whole.

In addition, it should be noted that Pidvysotskyi was respected not only among Russian and Ukrainian scientists, but also among foreign ones. Zilberberg wrote about his trip abroad and conversation with Leyden. Leyden said: "It is easy for 
us to remember the names of Russian doctors, except for Mechnikov, they all begin with 'P'—Pirogov, Pavlov, Pidvysotskyi' (Zilberberg, 1913).

\section{References}

CDIAK = Centralnyi derzhavnyi istorichnyi arkhiv Ukrainy, F 708, op 337, p. 49, Ukrainian State Historical Archives.

Derzhavnyi arkhiv mista Kyiva, F 16, c 4806, op 330, State Archive of the City of Kyiv.

Derzhavnyi arkhiv mista Kyiva, 'Kyivskyi universytet,' F 16, c 4806, op 465, p. 23, State Archive of the City of Kyiv.

Gamaliya, V. M. (2013), Rozvytok mikolohiyi ta fitopatolohiyi v Kyivskomu universyteti u druhij polovyni XIX stolitya, Kharkov: Vestnik NTU "HPI", no. 10, pp. 15-21.

Geraschenko, S. B.; Deltsova O. I. \& Chaikovsky, Y. B. (2013), 'Niuhovi nervovi stovburovi klitunu (neurogenesis v dorosluh),' Vicnuk morfologiy, no 2, pp. 456-462

Klein, B. I. (1957), 'Spogadu pro V. V. Pidvysotskyi,' Mikrobiologichnyi zhurnal, vol. 19, no. 3, pp. 65-68.

Klymenko, V. N. (1957), 'Vladimir Valeryanovych Podvysotsky,' Vrachebnoe delo, no. 6, pp. 660-661.

Lomynsky, F. I. (1882), 'K voprosu o delenii nervnykh kletok,' Prilozheniia k protokolam zacedanii Ob-va kyiv. Vrachei za 1881-1882, no. 3, pp. 1-32.

Ming, G. L. \& Song, H. (2011), 'Adult neurogenesis in the mammalian brain: significant answers and significant questions,' Neuron, vol. 70, no. 4, pp. 687-702. https://doi.org/10.1016/j.neuron.2011.05.001

Podvysotsky, V. V. (1884) 'O kefire', Prilozhenia k protokolam zacedanii Ob-va kiev vrachei za 1882-1883, pp. 27-61.

Podvysotsky, V.V. (1886), Vozrozhdenie pechenochnoy tkani u mlekopitayushchih zhivotnih, Kyiv: [eksperim. izsled.].

Podvysotsky, V. V. (1886), Novue tochki zreniya dlia obosnovaniia teorii razdrageniia pri proishozhdenii racov i drugikh zlocachestvennyh opukholeii.

Ruda, S. P. (2007), 'Professor V. Pidvysotskyi (do 150 richya s dnya narodgennya)', Nauka I naykoznavstvo, no. 3, pp. 128-132.

Savchenko, I. G. (1894), Sporovykovya chuzheyadnya v zlokachestvennyh opuholyah, Kyiv: Univ. izvestiya.

Sirotynyn, N. N. (1964), 'K 50-letiiu so dnia smerti V. V. Podvysotskii,' Arkhiv patologii, no. 8 , pp. $85-87$.

Stefansky, V. K. (1912), Difteria i ee lechenie, Odessa: Izdanie zhurnala "Terapevticheskoe obozrenie". 
Tarasevich, L. A. (1898), 'Izmeneniia v tsentralnuyu nervnuyu sistemu v sluchae smerti cheloveka ot golodaniya posle 35 dnei,' Russkii arkhiv patologii, klinicheskoi meditsiny i bakteriologii, vol. 5, no. 6, pp. 687-693.

Vasilyev, K. G.; Zaporozhan, V. N. \& Zanchevskaya, T. A. (2003), Vladimir Valerianovich Podvysotskii. Istoriko-biograficheskii ocherk, Odessa: Odesskii Med. Universitet.

Zabolotnyi, D. C. (1957), Izbrannie trudi, vol. 2, Kyiv: Izd-tvo AN USSR.

Zilberberg, L. A. (1913), 'Zametka, posviaschennaia pamyti pokoinogo professora V. V. Podvysotsky,' Russkii vrach, no. 7, pp. 237-238.

Liudmila Klymenko, physiologist, Candidate of Historical Sciences (in the field of history of science), associate professor at the Department of Physiology of Bogomolets National Medical University. She lectures the course of physiology and neurophysiology. She is the author of more than 50 research works on the history of physiology and medicine, among them the monograph History of the Formation and Development of Physiological Schools in Kyiv (The End of the Nineteenth and Twentieth Centuries). The main directions of her research are the history of physiological schools, and the role of the Ukrainian Society for Physiology in the development of physiology. 